\title{
The Impact of Distance Learning Requirements in Achieving Learning Outcomes During COVID- 19 Pandemic A study at Private Jordanian universities
}

\author{
Dr. Basem Barqawi ${ }^{1}$, Dr. Sahar Abu Bakir ${ }^{2}$ \\ ${ }^{1,2}$ Amman Arab University \\ 1basem68@hotmail.co.uk
}

\begin{abstract}
Despite that the system of higher education has been greatly affecting during the crisis of COVID-19, the Higher Education institutions forced to adapt to the new situation quickly and change the models of education from traditional system to distance learning system because of the increasing of student enrollments. Although there are different systems of Distance Learning which helps students get their education, still doubts of achieving the planed learning outcomes.

The aim of this paper is to try understand the most requirements needed to build a good distance learning system, and to know the impact of distance learning requirements in achieving learning outcomes during COVID-19 at the private Jordanian universities.

The results revealed that the Jordanian Private Universities operating at Amman are aware of the importance of distance learning requirements (The Human Resources, the Infrastructure, the Academic, the Financial, and the Managerial). And the learning outcomes (the knowledge, skills and competencies) were achieved by using distance learning as a substitute of face to face education.

For this purposes a purposive sample was selected consisted of (11) Universities that are operating at AmmanGovernorate, and the sampling unit was consisted of those who occupied the positions of dean and head of academic department in the (11) universities, and their number reached (235).

The most important recommendation of this paper is to strengthen the human resources, the infrastructure and the academic requirements, and to get attention more to the financial and the managerial requirements on achieving leaning outcomes.
\end{abstract}

Keywords

Online Learning, Learning Outcomes, Requirements of Distance Learning.

Article Received: 10 August 2020, Revised: 25 October 2020, Accepted: 18 November 2020

\section{Introduction}

The COVID-19 Pandemic is a global crisis, it is affected the whole sectors around the world, which in turn has worked to change the business environment. The system of higher education has been greatly affecting during the crisis of COVID-19, the Higher Education institutions forced to adapt to the new situation quickly and change the models of education from traditional system to distance learningsystem (Berg 2020).

These challenges are facing the higher education institutions now a days. On one hand, intuitions should adapt to new systems of education that grantee the quality of student'soutcomes, taking into consideration the academic requirements, and one the other hand, the increasing of student enrollments (Sergey at el. 2020).

\section{Definition of Distance Learning}

Distance learning is "A planed teaching/ learning experience that uses different methods of technologies to reach learners at a distance and is designed to encourage learner interaction and certification of learning" (Sylvi and Milawati 2020). While Budiastra at el (2020) mentioned that, distance learning "It is not always about learning new content, but to be able to access to sourcesof knowledge when it is needed". It is about combining online interaction using online courses at traditional- placed classroom, the students in distance learning can learn without depending on faculty members completely (Mouchantaf 2020).
The main factor of Distance Learning is that there is a distance between students and instructor and there is no best system used in distance learning, "it has developed from having cognitive behavioral pedagogical roots, to sociconstructivist learning and most recently to connectivity learning" (Berg 2020).

\section{Purpose of the Study}

The purpose of this study is to find out the impact of Covid19 pandemic and challenges facing the higher education in Jordan. On other words, this study aims to know the requirements needed to enhance student outcomes of higher education programs using the distance learning model from views of faculty members in private Jordanian higher education universities.

\section{Requirements for success Distance Learning}

The distance learning system should contain user guides offering system administration, academic functions, infrastructures platform. The distance learning should fit these functions and connected them on one platform at easer and single interface. In addition, the distance learning should be able to access and connected any future requirements (Arona and Srinivasan 2020)

The institution shoulddevelop andimplementan online learning system strategy which identified responsibilities, evaluation, support programs, and development. Bojovic at 
el (2020) mentioned that to have a success distance learning the system should have five phases:

Preparation phase (the course objectives, student learning needs, technical capabilities, organizational capabilities).

Planning phase (learning resources, testing and selection of distance learning platform, instructors training, students training)

Implementation phase (upgrade of IT infrastructure, redesign of network, technical support)

Operation phase (teaching and learning, tracking activities, infrastructure monitoring)

Evaluation phase (knowledge assessment, instructors and students feedback, it infrastructure performances)

According to some literature reviews (Arona and Srinivasan 2020, Durriyah and Zuhdi 2018, Mouchantaf 2020) the requirements for success distance learning should include the following:

\section{Administration Requirements}

Institutions should have an online learning system plane in short and long time including all facilities, hardware, software, and replacement during the implementation, development, and evaluation phases. The distance learning system must support the required standards such as: managerial, admission and registration, human resources, finance, instructor, student, guest, evaluator and reviewer) and any future requirements (Banna at el 2015).

The system should support the admission and registration requirements to make the process and the functions of admission and registration connected with the academic such as: evaluation schemes, anonymous assessment, student attendance sheet, and student results module. In addition, the admission and registration should be connected directly with finance system (to pay the fees) and academic counselor (to register new courses). So, student can enrolled in easer way and from a single interface (Lewis at el 2015). In addition, the online learning system should support students to get access to library and any other learning resources, and make connections to all support services such as: consular, academic advising, financial aid, participate in any events, any institution publications and career planning(Sergi at el 2020).

Moreover, it is necessary to link the administration of education institution (managerial, finance, and human resource departments) with the distance learning system to be updated continuously on the progress of work and take appropriate decisions at the right time(Weidlieh and Bastiaens 2018).

For the financial aspect, it is important to support the distance learning system in all aspects, to provide financial aid to student, the process of paying tuition fees any paying the salaries of faculty and administrative staff in the educational institution. For the human resource department, it is important to link the distance learning system with human resource because it is concern with aspects of appointing faculty members and training them to use the distance learning system in addition to train them how to develop courses syllabus and academic programs plans (Luna at el 2019).

\section{Academic Requirements}

"Distance learning plays a vital role in the development of new pedagogies, the asynchronous courses can facilitate modern learning paradigms, and the courses are labeled as hybrid, blended, or mixed describe any combination of the face-to-face and online (Bojovic at el 2020). In distance learning, classes are taken in a different format such as: live session, web pages, discussion group, pre-recorded lectures, chat, zoom, Microsoft Teams, Video conferencing (Mouchantaf 2020).

In order to exchange, update, and share the learning material, the distance learning system must store and manage learning content of all users on a special platform. This platform can help in summary, keep different versions, and track the history of content management files. In addition, this platform should help in easily and quickly share academic resources with a drag-and-drop facility (Sergey 2020).

Instructor upload material with deadline for submission of assignments in distance learning system which gives students a flexible time for study, which shifted the control from instructor to student (Xiao 2017).

(Weidlieh and Bastiaens 2018) mentioned that distance learning has some disadvantages for instructors, such as: instructors spend lot of time in preparing course materials and track achievements, spent time to solve problems, and give a lot of motivation and encourage to students. In addition instructor is available for long time every day. But the distance learning reduce the paperwork of instructor and student, and gives a flexibility of faculty and student to learn anytime and anywhere and using a variety of communication modes.

In order to deliver the lectures as planned, instructors should be trained and aware of how to prepare a classes from home, because there is different skills among instructors on interaction with students, according to their age and awareness, instructor are differ in their teaching tools such as express critical thinking, assess, provide individual support, and solve problems (Apariciao 2019). Moreover, faculty should be supported ininstructionaldesignanddevelopmentof

coursematerials,includingasappropriate, graphicdesigners, mu limedia specialists,programmers and librarians, andalso help instructors to send messages and write notes to students and perhaps write a reports regarding students' progress and performance of reports to deans and parents (Alqurashi 2019)

Cole at el (2014) and Berg (2020) mentioned that, institution should ensuresthat:

The intended outcomes for programs and courses should be the same with the tradition programsandcourseslearning outcomes.

The performance of students is the same of traditions learning, and make sure that the environment of online learning support students interactions with instructors through designing and design academic courses in appropriate methods either in asynchronousorsynchronous.

The integrityofstudentworkare honesty and limit to any fraud, including,examinations protocol and authenticating studentwork (Budiastra at el 2019). 
The institution should also reduce instructors workloadbecause of time spend in teaching, developing, redesign and evaluate the content and curriculum to fit the online methods and improve the interaction with students. In addition to the time spend in online interaction with students because the distance learning is mostly student-oriented rather than instructor-oriented and instructor needs to bridge the gap of study materials with students through distance learning by interaction with students (Berg 2020)

\section{Infrastructure Requirements}

The distance learning system should have a plagiarized model to access the databases that can be used to test the assignments and research papers submitted by students and highlight the plagiarized content and overlap percentage and how be integrity and student data at the online learning system (Guan at el 2020).

The distance learning should have an integrated model of virtual classroom and videoconferencing helps students to response at real time or store these lectures, make a discussions students-students and instructor-students, sharing the screen and lecture presentation, have a link that can help in student engagement with community and other groups outside the classroom and help in extracurricular activities for both students and instructors (Budiastra at el 2019).

Talan and Sevine (2019) mentioned that, the distance learning system should maintains:

-Studentinformation within the comprehensive e-learning environment,

- $\quad$ Sufficientinternetbandwidth,servercapacity,andstaffto supportthe operationofthe e-learningenvironment;

Ane-learningenvironment, consisting of a learningorcoursemanagementplatform,relatedcommunicatio nstools and support resources/serviceswhichisadequate tomeetthedemandsofitse-

learningprogramsandcourses, andofthe faculty members and students involvedin e-learning

While Hodges (2020) suggest that e-learning system should provide sufficienttechnicalsupportand training programs tostudentsandfacultytoensure the appropriate interaction and delivery ofacademic courses

\section{Student Outcomes}

All academic courses has intended learning outcomes and they are linkage and contribution to the program outcomes. These outcomes are measuring student's Knowledge, skills, and aspects of competences (autonomy and responsibility, role of context, andself-development). These outcomes are regularly reviewed and evaluated in a variety of ways, uses both direct and indirect evaluative tools such as: courses assessment tools, involving instructors, students, attrition rates, completion rates, employability of graduates and external advisory committees, in addition to get feedback from employment of its graduates.Then, the results should be analysed to show that students acquire the outcomes needed as planed (knowledge, skills and competencies) according to course learning outcomes. Finally, make the improvements needed to reach the quality of programs as planned (Luna at el 2019). And this is one of the objectives of this study.

According to United Arab Emirates Qualifications Framework (2020), programs learning outcomes are a precise, clear and specific description of the learning outcomes that learner possesses upon graduation from academic institutions, and they could find in three levels:

a. Knowledge, is the specification and quality of the extent of knowledge in which the learner is integrated.

b. Skills, how the learner chooses the skill that he learned to deal with multi-level problems and issues

c. Aspects of competences, which could be found in three component:

Autonomy and responsibility, how the learner acts alone and through a team within the framework of the acquired skills.

Role of context, can learner implement and apply the knowledge and skills he acquired in his expected field of work?

- $\quad$ Self-development, the extent to which the learner can engage in new situations and acquired new knowledge and skills.

\section{The Case of Jordan}

The Higher Education Accreditation and Quality Assurance Commission (HEAC) is the responsible body for all public and private universities in Jordan. Since Covid-19 started, HEAC issued a set of decisions to regulate higher education system and obligate universities to start using the distance learning (off-campus) since spring semester 2019/2020, such as:

- $\quad$ All Jordanian universities should shifted to online learning instead of face-to-face learning.

Universities have a freedom to use any methods to transmit course information such as Zoom and Microsoft Teams through a proper learning management system.

Universities have a freedom to choose any teaching and learning system and materials that is appropriate for courses being taught. And supported by appropriate technology,

Universities should issue a guidance on the practices of evaluating the teaching and learning methodologies;

Ensures that student/faculty ratio is applied according to the approved standard for each level of the course, and programs.

The course syllabus contains of all necessary information for students to understand the required of them, in addition to the content of the course distributed on weekly basis

- Universities should offer courses in a balance between theoretical and practical applications according to the course being taught.

These decisions have been evaluated on semester basis and been updated according the COVID-19 pandemic situation. 


\section{Methodology}

\section{The population, sample and sampling unit}

Jordanian Private Universities represented the population of the study, according to the Jordanian Ministry of High Educationreports the total No. of Private universities $=(21)$ distributedalong the three regions of the Jordanian kingdom. A purposive sample was selected consisted of (11) Universities that are operating at AmmanGovernorate.

Meanwhile the sampling unit was consisted of those who occupied the positions of dean and head of academic department in the (11) universities, and their number reached (235).

\section{The conceptual model and hypotheses:}

The study aimed to test the availability of distance learning requirements in the (11) universities in terms of (Human resources requirements, infrastructure, academic, financial, and finally the managerial requirements).

According to (Weidlieh and Bastiaens 2018), the Human Resources, financial requirements and managerial requirements were joined together into one variable (administrative requirement). However, due to their special status of the private Jordanian universities, the researchers decided to separate (the financial, human resource, and the managerial requirements so that each of them constitutes an independent requirement in its own.

And then the study was intended to measure the impact of these requirements (acted as the independent variable/s), on students learning outcomes (knowledge, skills and competencies), acted as the dependent variable/s.

The independent variable

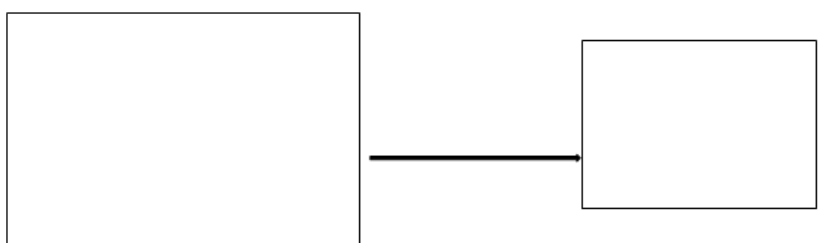

Figure (1) the conceptual model

To achieve the objectives of the study the researchers developed the following

\section{hypotheses:}

H1: The Distance Learning requirements (Human resources requirements, infrastructure, academic, financial, and finally the managerial requirements) are available at The Jordanian Private Universities.

$\mathrm{H} 2$ : there is a statistically significant impact of (distance learning) requirements on achieving students learning outcomes (knowledge, skills and competencies),

\section{The study tool:}

The needed data and information were collected through developed questionnaire based on previous literature.

The first part of the questionnaire measured the characteristics of the sampling unit, while the second part was designed to measure the independent variable requirements, 4 questions for each one of them with a total of (20) questions.

And the three dimensions of the dependent variable were measured through 12 questions.

The respondents evaluated the questions based on Likert 5 scale of agreement ranged between (1) point for strongly disagree to (5) points for strongly agree.

232 questionnaires were distributed electronically, 176 questionnaires were retrieved and all were valid for statistical analysis.

\section{Statistical Analysis Results:}

\section{The tool reliability}

The researchers tested the reliability of the questionnaire by using Cronbach alpha coefficient. The results show that the values for all the variables were above (70\%), according to Sekeran \& Bougie(2003) if this measurement $\geq 70 \%$ it indicated an internal consistency of the questionnaire questions.

\section{Therespondents' characteristics:}

By using frequencies and percentage the respondents' characteristics were as follows:

When it comes to Gender $12.6 \%$ are females, $87.4 \%$ are males.

$5.8 \%$ of the respondents were less than 40 years old, $79.3 \%$ were between $40-50$ years old and $14.9 \%$ were more than 50 years old.

The work experience for them all was more than 5 years in the academic filed

\section{The Descriptive statisticsresults:}

Table (1) shows the means and standard deviations of the independent (5) sub variables questions, and also for the dependent (3) sub variables questions.

The results show that all the means are above (3.66) which indicated high levels of respondents' acceptance related the availability of distance learning requirements and also the achievements of students learning outcomes.

Table (1) descriptive statistics results

\begin{tabular}{|c|c|c|}
\hline \multicolumn{3}{|c|}{ Independent variable/s } \\
\hline $\begin{array}{l}\text { Distance learning } \\
\text { requirement }\end{array}$ & Mean & Standard deviation \\
\hline Human resources & 3.9989 & .50709 \\
\hline Infrastructure & 3.9818 & .56862 \\
\hline Academic & 4.0034 & .33499 \\
\hline Financial & 3.9432 & .30942 \\
\hline Managerial & 3.9693 & .47852 \\
\hline \multicolumn{3}{|c|}{ Dependent variable/s } \\
\hline Learning outcomes & Mean & Standard deviation \\
\hline Knowledge & 3.8636 & .73852 \\
\hline Skills & 3.8102 & .78450 \\
\hline competencies & 3.7830 & .83409 \\
\hline
\end{tabular}

4. Hypotheses testing results:

\section{H1 results:}

To test this hypothesis one sample t test used with (3)value for comparison and $95 \%$ confidence interval. 
Table (2) shows that all the sig values of $t$ are less than 0.05 and accordingly $\mathrm{H} 1$ will be accepted to confirm that the Jordanian private universities have the distance learning requirements.

Table (2) one sample t test results

\begin{tabular}{|l|c|c|}
\hline Distance learning requirements & T value & Sig. (t tailed) \\
\hline Human resources & 26.132 & .000 \\
\hline Infrastructure & 22.907 & .000 \\
\hline Academic & 39.738 & .000 \\
\hline Financial & 41.560 & .000 \\
\hline Managerial & 26.149 & .000 \\
\hline
\end{tabular}

$\mathrm{df}=175$ Test value $=3 \quad 95 \%$ confidence interval

\section{H2 results:}

To test $\mathrm{H} 2$ the researchers calculated multiple regression. The results displayed in Table (3) show that the correlation between all the independent variable and the dependent $=$ 0.783 indicated a positive relationship between the 2 variables.

The table shows that $\mathrm{R} 2=0.613$ whichmeans that $61.3 \%$ of the dependent variable variation is explained by the independent variables.

$\mathrm{F}$ value $=53.846$ at $0.000 \mathrm{sig}$ level indicated that the regression model is suitable for testing $\mathrm{H} 2$.

Based on $\mathrm{t}$ sig values in comparison to $<0.05$ it is indicated that there is a statistically significant impact of distance learning requirements (the human resources, the infrastructure and the academic) on achieving students learning outcomes.

The two sub variables (the financial and the managerial) sig values were $>0.05$ which indicated that they have no statistically significant impact on students leaning outcomes.

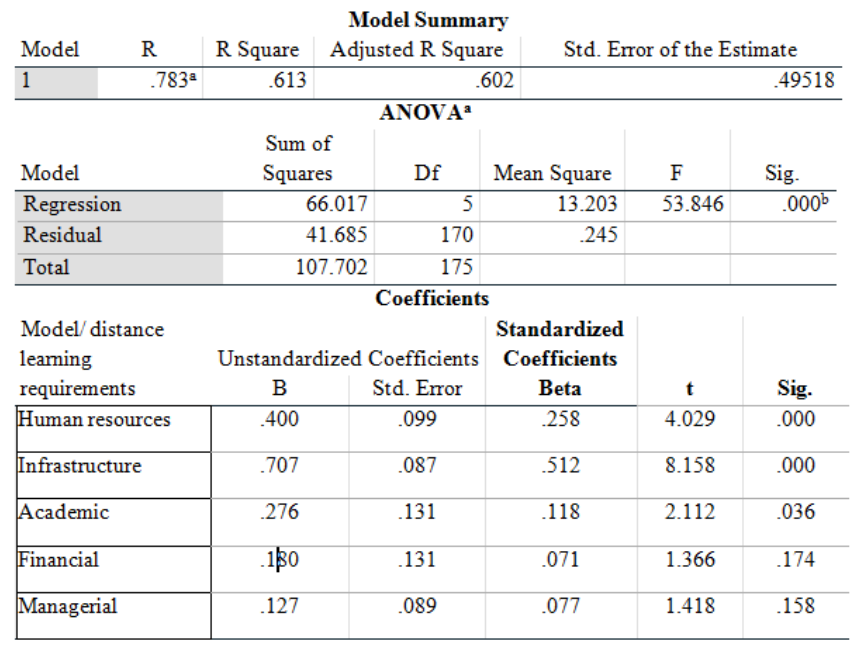

The results revealed that the Jordanian Private Universities operating at Amman are aware of the importance of distance learning requirements (The human resources, the technical, the academic, the financial and the managerial).

Based on the dependent sub variables means, (the knowledge, skills and competencies ) it is obvious that the respondents agreed that the surveyed universities achieved these learning outcomes by using distance learning as a substitute of face to face education .

\section{Recommendations}

Institutions offered online programs and courses should, a. Develop an e-learning manual includes, Policy and procedures for using the online system for delivery the courses (e.g. interaction between instructors and students, and students and students, asynchronous and synchronous interaction, the security of testing and examinations).

b. Clarify instructors, students, and administration department (e.g. Admission and Registration, students affairs, finance, and information technology), roles and responsibilities in implementing the distance learning system and trained them

c. Focus and strengthen the human resources, the infrastructure and the academic requirements,

d. Get attention more to the financial and the managerial requirements on achieving leaning outcomes.

\section{References}

[1] Alqurashi, E. (2019). Predicting student satisfaction and perceived learning within online learning environments, Distance Educ. 40 (2019), 133-148.

[2] Aparicio, M. (2019). Gamification: A key determinant of massive open online course (MOOC) success, Inf. Manag. 56 (2019), 39-54.

[3] Arora, K., \& Srinivasan, R. (2020). Impact of pandemic COVID-19 on the teaching learning process: A study of higher education teachers. Prabadhan: Indian Journal of Management, 2020, 13 (4).

[4] Banna, J., Lin, M. G., Stewart, M., \& Fialkowski, M.K. (2015). Interaction matters: Strategies to promote engaged learning in an online introductory nutrition course. MERLOT Journal of Online Teaching and Learning, 11(2), 249-261.

[5] Berg, I., (2020). Context Matters: Studeent Experiences of Interaction In Open Distance Learning. Turkish online Journal of Distance Education-TOJDE. Vol. 214 Article 13.

[6] Bojovic, Z., Bojovic, P., Vujosevic, D., \& Shu, J., (2020). Education in Times of Crisis: Rapid Transsition to Distance Learning. Compat Appl. Eng. Edu. Vol. 28, pp 1467-1489.

[7] Bozkurt, A., Honeychurch, S., Caines, A., Bali, M., Koutropoulos, A., \& Cormier, D. (2016). Community tracking in a cMOOC 
and nomadic learner behavior identification on a connectivist rhizomatic learning network. Turkish Online Journal of Distance Education, 17(4):4-30.

[8] Budiastra, A., Erlina, N., \& Wicaksono, I. (2019). Video-based interaction through teacher working group forum to increase elementary school teachers' professionalism. New Educational Review, 57, 187-199. Advances in Social Sciences Research Journal (ASSRJ) Vol.7, Issue 2 Feb-2020 Copyright (C) Society for Science and Education, United Kingdom 165 Budiastra,

[9] Budiastra ,A., Kusmawan, U., Eicaksonon, I., \& Kartimi, I., (2020). The Use of Natural Sciences Kits in Distacne Learning For Higher Education of Bachelor of Elmentary School Teacher Education Program. Adcaces in Social Sciences Research Journal. Vol. 7, No. 2.

[10] Ching, Y.-H., Hsu, Y.-C., \& Baldwin, S. (2018). Becoming an online teacher: an analysis of prospective online instructors' reflections. Journal of Interactive Learning Research, 2018, 29(2), 145-168.

[11] Cole, T., Shelley, J., \& Swartz, B. (2014). Online instruction, e-learning, and student satisfaction: A three year study, Int. Rev. Res. Open Distance Learn. 15 (2014), 111-131.

[12] Durriyah, T.\& Zuhdi, M., (2018).Digital Literacy With EFL Student Teachers: Exploring Indonesian Student Teachers' Initial Perception About Integrating Digital Technologies Into a Teaching Unit. International Journal of Education \& Literacy Studies, 2018,6(3), 53-60.

[13] Erasmus, F. \& Grebe, M. (2016). Availability of Study Time for Undergraduate Finance Students at an Open and Distance Learning Institution in South Africa. Journal of Higher Education in Africa / Revue de l'enseignement supérieur en Afrique, 14 (1): 141-154

[14] Erlina, K., \& Wicaksono, I. (2019). The factors affecting teachers' readiness in developing science concept assessment through inquiry-based learning process in elementary schools. Advances in Social Sciences Research Journal, 6(9), 355-366.

[15] Freeman, L.,\& Urbaczewski, A., (2019). Critical success factors for online education: Longitudinal results on program satisfaction, Commun. Assoc. Inf. Syst. 44 (2019), 30-645.

[16] Guan, J., Chen, C., \& Zhong, S., (2020). Strategies for the prevention and management of coronavirus disease, Eur. Respir. J. 55 (2020), 2000597.

[17] Hodges C. (2020). The difference between emergency remote teaching and online learning, available at https://er.educause.edu/articles/2020/3/thedifference-between-emergencyremoteteaching-and-online-learning

[18] Joksimović, S. Gaševic, D., Kovanović, V., Riecke, E., \& Hatala, M., (2015). Social presence in online discussions as a process predictor of academic performance. Journal of Computer Assisted Learning, 31(6), 638-654.

[19] Jordan, K. (2014). Initial trends in enrolment and completion of massive open online courses, Int. Rev. Res. Open Distrib. Learn. 15 (2014), 133-160.

[20] Kauffman, H. (2015). A review of predictive factors of student success in and satisfaction with online learning, Res. Learn. Technol. 23 (2015).

[21] Lee, J., \& Martin, L., (2017). Investigating students' perceptions of motivating factors of online class discussions. International Review of Research in Open and Distributed Learning, 18(5), 148-172.

[22] Lewis, S., Whiteside, A. \&Dikkers, A, (2015). Providing Chances for Students to Recover Credit: Is Online Learning a Solution?. Exploring Pedagogies for Diverse Learners Online (Advances in Research on Teaching. Emerald Group Publishing Limited.Vol. 25. pp. 143-157.

[23] Luna, O., Cruz, L., \& Arce, O., (2019). Achievement, Engagement and Student Satisfaction in a Synchronous Online Course, IEEE Global Eng. Educ. Conf., IEEE, Dubai, UAE, 2019, pp. 124-132. 
https://ieeexplore.ieee.org/document/ 8725259

[24] Sylvi, M., \&Milawati, M., (2020). Distance Learning Innovation Strategy in Indonesia During the Covid-19 Pandemic. Advances in Social Sciences, Education and Humanitities Research. Vol. 488.

[25] Mouchantaf, M., (2020). The Covid-19 Pandemic: Challenges Faced and Lessons Learned Regrarding Distacne Learning in Lebancese Higher Education Institutions. Theory and Practive in Language Studies. Vol. 10 Mo. 10, pp: 1259-1266.

[26] Pavalche-Ilie, M. \& Cocorada, S. (2014). Interactions of students' personality in the online learning environment. Procedia Social and Behavioural Sciences, 128, 117-122.

[27] Pham, L. (2019). Development and validation of an instrument to measure student perceived e-learning service quality, Int. J. Enterp. Inf. Syst. 15 (2019), $15-42$.

[28] Pham, L., Stan, W., \& Ronald, B. (2018). Student perceptions of e-learning service quality, e-satisfaction, and e-loyalty, Int. J. Enterp. Inf. Syst. 14 (2018), 19-40.

[29] Rodríguez, O., González-Gómez， F. \& Guardiola, J. (2019) Do course evaluation systems have an influence on e-learning student satisfaction? Higher Educ. Evaluation Dev. 13 (2019), 18-32. .

[30] Sekaran, U., \& Bougie, R. (2003). Research Methods for Business: A skillbuilding approach. New York: John Willey and Son. Inc Year.

[31] Sergey V., Alina M., Konstanitin V., Slaveyko g., \& Vitaliy O. (2020). Review of Distance Learning Solutions Used During the Covid-19 Crisis. Advances in Socience, Education and Humanitites Research, Vol. 505.

[32] Siregar, E., Rajagukguk, J., \& Sinulingga, K. (2020). Improvement of Science Process Skills Using Scientific Inquiry Models With Algodoo Media and Quotient Adversity in High School Students.
Journal of Transformative Education and Educational Leadership, 2020, 1(2), 53-65.

[33] Talan, T., \& Sevinc, G. (2019). The effect of a flipped classroom on students' achievements, academic engagement and satisfaction levels, Turkish Online J. Distance Educ. 20 (2019), 31-60.

[34] United Arab Emirates Qualification Framework (2020), available at: https://www.nqa.gov.ae/en/ourresponsibility/qualifications-frameworkdepartment/designing-of-theqfemirates.aspx. Date of check the website 20/1/2021.

[35] Van den Berg, G. (2017). Learning theories and the use of technology in the classroom. In Swart, E. and Eloff, I. (Eds), Understanding educational psychology (pp. 69-76). Cape Town.

[36] Wang, Z., Chen, L., \& Anderson, T. (2014). A framework for interaction and cognitive engagement in connectivist learning contexts. The International Review of Research in Open and Distributed Learning, 15(2). doi:http://dx.doi.org/10.19173/irrodl.v15i2 .1709

[37] Weidlich, J., \& Bastiaens, T.J. (2018). Technology matters - The impact of transactional distance on satisfaction in online distance learning. International Review of Research in Open and Distributed Learning, 19(3), 222-242

[38] Xiao, J. (2017). Learner-content interaction in distance education: The weakest link in interaction research. Distance Education, 38(1), 123-135. 